\title{
Carbon Budget Dynamics over a Rain-Fed Maize Agricultural Ecosystem in Northeast China and Its Regulation
}

\author{
Rongping Li1 ${ }^{*}$, Guangsheng Zhou ${ }^{2}$, Li Zhou ${ }^{2}$, Yang Yang ${ }^{3}$ \\ ${ }^{1}$ Liaoning Institute of Meteorological Science, Shenyang, China \\ ${ }^{2}$ Chinese Academy of Meteorological Sciences, Beijing, China \\ ${ }^{3}$ Jinzhou Ecological and Agricultural Meteorology Center, Jinzhou, China \\ Email: *rongpingli@163.com
}

How to cite this paper: Li, R.P., Zhou, G.S., Zhou, L. and Yang, Y. (2017) Carbon Budget Dynamics over a Rain-Fed Maize Agricultural Ecosystem in Northeast China and Its Regulation. Open Journal of Ecology, 7, 377-391.

https://doi.org/10.4236/oje.2017.76027

Received: April 26, 2017

Accepted: June 20, 2017

Published: June 23, 2017

Copyright $\odot 2017$ by authors and Scientific Research Publishing Inc. This work is licensed under the Creative Commons Attribution International License (CC BY 4.0).

http://creativecommons.org/licenses/by/4.0/ (c) $\underset{\mathrm{EY}}{\mathrm{i}}$ Open Access

\begin{abstract}
Based on the eddy-covariance observation data over rain-fed maize agricultural ecosystem during 2005-2011, the dynamics of net ecosystem $\mathrm{CO}_{2}$ exchange (NEE) and its control mechanism were analyzed in the present study. We found that the average carbon budget of non-growing season, growing season and annual were $153.16-202.03 \mathrm{~g} \mathrm{C} / \mathrm{m}^{2},-689.36--488.17$ $\mathrm{g} \mathrm{C} / \mathrm{m}^{2}$, and $-316.96--487.33 \mathrm{~g} \mathrm{C} / \mathrm{m}^{2}$, respectively. Maize carbon content of grain yield was -226.6 - $-339.94 \mathrm{~g} \mathrm{C} / \mathrm{m}^{2}$, accounting for $55.4 \%$ of carbon budget in the growing season. From sowing to seven-leaf stage, the carbon budget of this ecosystem was characterized by carbon release, with the rate of $0.028 \pm 0.0056 \mathrm{mg} \mathrm{CO} \mathrm{m}^{-2} \cdot \mathrm{s}^{-1}$. From seven-leaf to mature stage, the carbon budget was characterized by carbon absorption, with the rate of $-0.256 \pm$ $0.0693 \mathrm{mg} \mathrm{CO} \mathrm{CO}_{2} \mathrm{~m}^{-2} \cdot \mathrm{s}^{-1}$. The key meteorological factors affecting annual carbon budget included daily average temperature $(R=-0.81, P=0.03)$ and saturated vapor pressure deficit $(R=-0.64, P=0.12)$. At the same photosynthetically active radiation (PAR) level, $\mathrm{CO}_{2}$ assimilation rate was linearly correlated with leaf area index $(P<0.05)$, and the slopes increased with PAR, indicating the increase in net ecosystem $\mathrm{CO}_{2}$ exchange in growing season was unlikely to be resulted from the extension of growing season. On the contrary, the carbon sink of rain-fed maize ecosystem in growing season might be decreased by extending the growing season ahead of the sowing date.
\end{abstract}

\section{Keywords}

Rain-Fed Maize, Carbon Budget, Dynamics, Regulation Mechanism, Northeast China 


\section{Introduction}

$\mathrm{CO}_{2}$ concentration in the atmosphere is being increased mainly due to human activities. In order to predict accurately future climatic change and its influence, it is rather critical to understand the dynamics of $\mathrm{CO}_{2}$ concentration in atmosphere [1]. In the short term, increasing $\mathrm{CO}_{2}$ absorption of terrestrial ecosystems has become one way to reduce $\mathrm{CO}_{2}$ concentration in the atmosphere [2]. $\mathrm{Al}$ though the farmland accounts for $12 \%$ of global surface areas [3], the annual net ecosystem $\mathrm{CO}_{2}$ exchange (NEE) of agricultural ecosystem is greater than other natural ecosystems [4]. Therefore, it is important to understand the carbon budget dynamics of different agricultural ecosystems and their regulations.

Northeast China, located in the east-Asian monsoon zone, has been warming and drying strongly during the latest 50 years [5]. The crop development and growth have been sharply influenced by the climate change in this region. Furthermore, agricultural ecosystem is one of main terrestrial ecosystem types in Northeast China, and its carbon budget plays an important role in the regional assessment of carbon budget. Maize is one of three major crops (Paddy rice, maize and wheat) in Northeast China, and its maize sown area is about $9.85 \times 10^{6}$ ha in 2011, accounting for $51.3 \%$ of grain sown area in Northeast China. The maize agricultural ecosystem in Northeast China is a typical rain-fed agriculture. Therefore, evaluating carbon budget dynamics of maize agricultural ecosystem in Northeast China and revealing its control mechanisms are critical to assess global carbon budget and to better understand the principle of carbon balance changes.

At present, eddy covariance technique has been widely used in quantifying carbon flux over agricultural ecosystem [6] [7] [8] [9], determining the effects of different agricultural measures on farmland carbon budget [10] [11] [12] [13], and exploring the control mechanisms of environmental factors on farmland carbon balance [14] [15]. However, these studies at present are mostly based on the short-term observation data, the results could not reveal the dynamics and control mechanisms of agricultural ecosystems on a year time scale. Generally, flux data of continuous many years (5 - 10 years) are needed to assess the inter-annual variation of carbon budget in agricultural ecosystem and its control mechanism at multi time scales [16]. Although the carbon budget and its affecting factors for rotation and un-tillage type of maize and soybean farmland are studied based on the flux data observed for a longer time [1] [4], there is little information on carbon budget of tillage rain-fed maize agricultural ecosystem with observation data of continuous years.

The objectives of this study are 1) to quantify NEE of rain-fed maize agricultural ecosystem at different development stages and different seasons (i.e., the growing and non-growing seasons and annual); and 2) to reveal control mechanisms of carbon budget in the most common tillage and continued rain-fed maize agricultural ecosystem, based on long-term eddy covariance data over rain-fed maize agricultural ecosystem in Northeast China during 2005-2011. 


\section{Materials and Methods}

\subsection{Study Sites}

The study site is located at Jinzhou Agricultural Ecosystem Field Experiment Station in the Northeast of China $\left(41^{\circ} 8^{\prime} 53^{\prime \prime} \mathrm{N}, 121^{\circ} 12^{\prime} 6^{\prime \prime} \mathrm{E}, 23 \mathrm{~m}\right)$. The climate is temperate monsoon. Its mean annual air temperature and precipitation are $9.4^{\circ} \mathrm{C}$ and $568.8 \mathrm{~mm}$ from 1951 to 2011, respectively. The nearly $70 \%$ of the annual precipitation occurs in summer (i.e., June, July, and August). The soils are clay loams, typical brown soil. The soil $\mathrm{pH}$ value and soil organic matter in the depths from 0 to $40 \mathrm{~cm}$ are $6.3 \%$ and $1.36 \%$, respectively.

The site is very flat and large fields with 43 ha, that provides sufficient upwind fetch with unstable condition. The maize was sowed in the end of April or the early of May after deep tillage and harvested in the end of September. The nitrogen fertilizer with $300 \mathrm{~kg} / \mathrm{ha}$ has been applied in soil before the sowing. After harvest, the field goes into the fallow period until the next year maize sowed period.

\subsection{Eddy Covariance and Meteorological Measurements}

Fluxes of carbon dioxide, water vapor and sensible were obtained by the eddy covariance method [16]. The observation system was composed of a three-dimensional ultrasonic anemometer (Model CSAT3: Campbell Scientific Instruments Inc., Logan, UT, USA) and an open-path infrared $\mathrm{CO}_{2} / \mathrm{H}_{2} \mathrm{O}$ gas analyzer (Model LI7500: LI-COR, Inc., Lincoln, NE, USA). The sensors were mounted 3.5 $\mathrm{m}$ above the ground.

The micro-meteorological data were also measured, including temperature and humidity (Model HMP45C, Vaisala Inc. Helsinki, Finland), precipitation (Model 52202, RM Young Co., Traverse City, MI, USA), wind speed and direction (034B, MetOne), net radiation (Model CNR1, Kipp and Zonen, Delft Netherlands), and photosynthetically active radiation (PAR) (Model Li190SB, LI-COR, Inc., Logan, UT, USA) and soil temperature (Model Platinum RTD, Omega Engineering Stamford, CT, USA).

\subsection{Flux Data Processing}

The raw data time series with a frequency of $10 \mathrm{~Hz}$ were calculated into the half flux data using the EdiRE software package [17]. Process procedure included the spike detection [18], coordinate rotate [19], spectral loss correction [6], and WPL-correction [20], The energy balance was examined by calculated linear regressions between the sum of latent heat and sensible heat and the value of net radiation subtract soil heat storage. The slope and intercept ranges of the regression function was $0.72-0.79$ and $6.08-19.72 \mathrm{~W} / \mathrm{m}^{2}$. Instrument malfunction, poor weather and low turbulent mixing will result with data gap [21]. 2.72\% $14.62 \%$ of annual data missed was attributed to the instrument malfunction and power failure. Low turbulent mixing (friction velocity less than $0.1 \mathrm{~m} / \mathrm{s}$ ), rainfall and other unpredictable situation caused another $15.80 \%-33.11 \%$ data missed. The numbers of the valid data in $2005-2011$ are $68.39 \%, 69.58 \%, 74.89 \%, 64.03 \%$, $70.40 \%, 57.04 \%$ and $64.27 \%$ of annual data, respectively. For this study, the short 
gap data $(<3 \mathrm{~h})$ were filled with linear interpolation, but the larger gap data ( $>3$ h) were filled with LookUp table method [21].

\subsection{Calculation of GPP and $\boldsymbol{R}_{\text {eco }}$}

The ecosystem respiration $\left(R_{e c o}\right)$ was evaluated using the Vant Hoff equation [Equation (1)]:

$$
R_{\text {eсо }}=R_{0} \exp \left(b T_{s}\right)
$$

where $R_{0}$ is the respiration at $0^{\circ} \mathrm{C} . R_{0}$ and $b$ are the regression parameters. The Vant Hoff equation was fitted using the soil temperature at $5 \mathrm{~cm}$ depth and the $\mathrm{NEE}$ at night when the friction velocity $\mathrm{u}^{*}>0.1 \mathrm{~m} / \mathrm{s}$. the parameter value were used to evaluate the $R_{\text {eco }}$ at daytime. The net ecosystem production (NEP) and gross primary production (GPP) were calculated using the following equation:

$$
\begin{gathered}
\mathrm{NEP}=-\mathrm{NEE} \\
\mathrm{GPP}=R_{\text {есо }}+\mathrm{NEP}
\end{gathered}
$$

\subsection{Maize Phenology, Grain Yield}

The maize phenology was observed every day after sowing seed according to the China Agriculture Meteorological Observation Criterion. The 40 maize plants were harvested at mature stage. The grain yield per square meter was calculated using the grain yield of the average single maize plant multiply to planting density per square meter. The carbon content in maize grain was calculated as follows:

$$
C_{g r}=\left(1-W_{g}\right) \cdot F_{c} \cdot Y
$$

where $C_{g r}$ is the carbon content of grain in unit area $\left(\mathrm{g} \mathrm{C} / \mathrm{m}^{2}\right), W_{g}$ represents the water content of maize grain (15.5\%), $F_{c}$ denotes the carbon conversion efficiency of maize grain (0.447), and $Y$ is the grain in unit area $\left(\mathrm{g} \mathrm{Grain} / \mathrm{m}^{2}\right)$ [1].

\section{Results}

\subsection{Meteorological Elements}

From 2005 to 2011, the range of precipitation was $444.2-809.3 \mathrm{~mm}, 330.5$ $637.5 \mathrm{~mm}$ and $53.7-171.8 \mathrm{~mm}$ for annual, growing season, and non-growing season, respectively, and the mean precipitation was $580.3 \mathrm{~mm}, 480.5 \mathrm{~mm}$ and $99.8 \mathrm{~mm}$, respectively (Figure 1(a)). Mean annual air temperature fluctuated between $11.59^{\circ} \mathrm{C}$ and $12.91^{\circ} \mathrm{C}$ with the mean value of $12.24^{\circ} \mathrm{C}$. Furthermore, mean annual air temperature for the nearly 3 years tended to be lower (Figure 1(b)). The minimum and maximum values of saturated vapor pressure deficit (VPD) were 0.52 and 0.74 , respectively (Figure $1(\mathrm{~b})$ ). The mean annual sun hours varied from 6.13 to $7.41 \mathrm{~h}$ with the mean value of $6.77 \mathrm{~h}$ (Figure $1(\mathrm{c})$ ). The mean annual wind speed varied from 2.61 to $2.92 \mathrm{~m} / \mathrm{s}$ (Figure $1(\mathrm{c})$ ).

\subsection{NEE Dynamics}

\subsubsection{NEE in Non-Growing Season}

During 2005-2011, half-hour $\mathrm{CO}_{2}$ exchange in non-growing season represented 


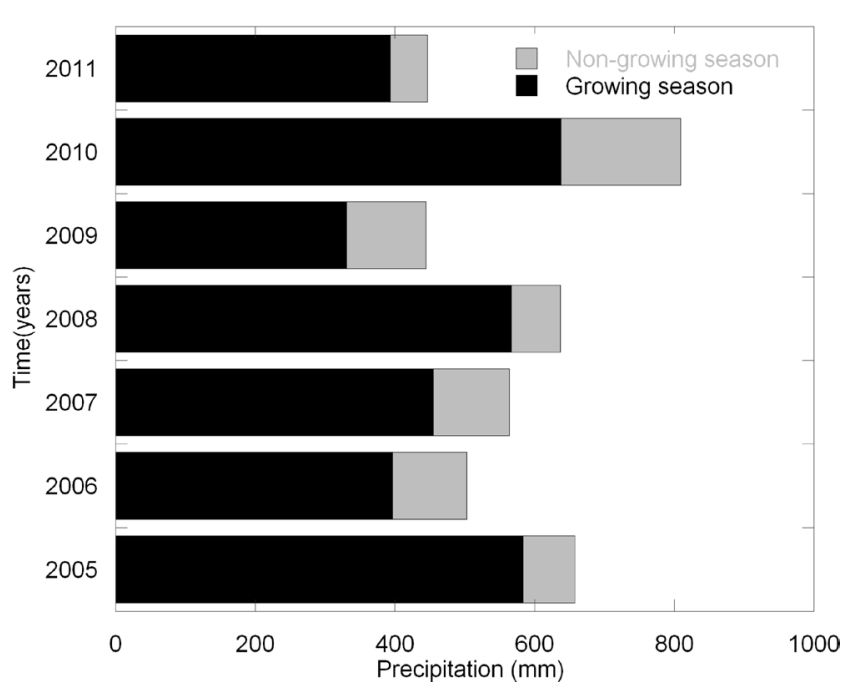

(a)

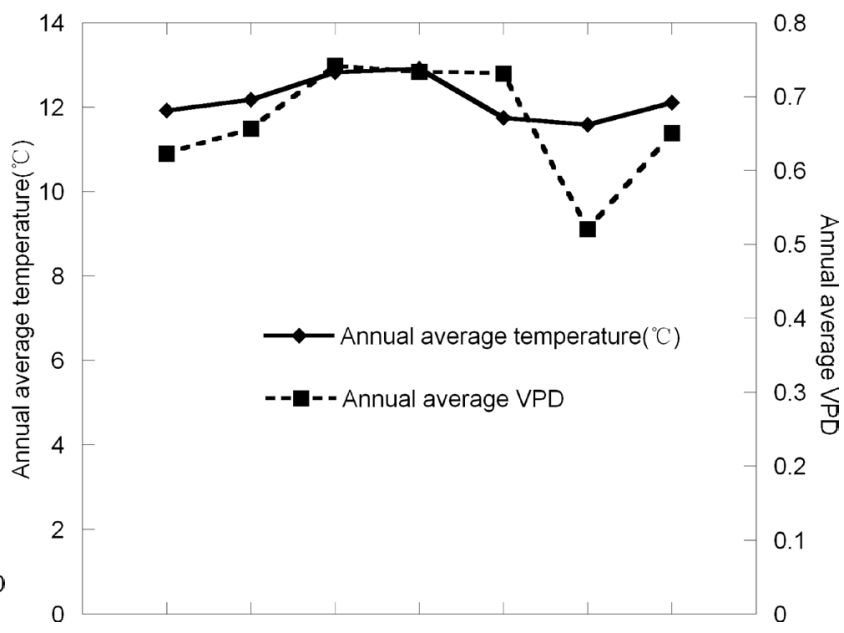

(b)

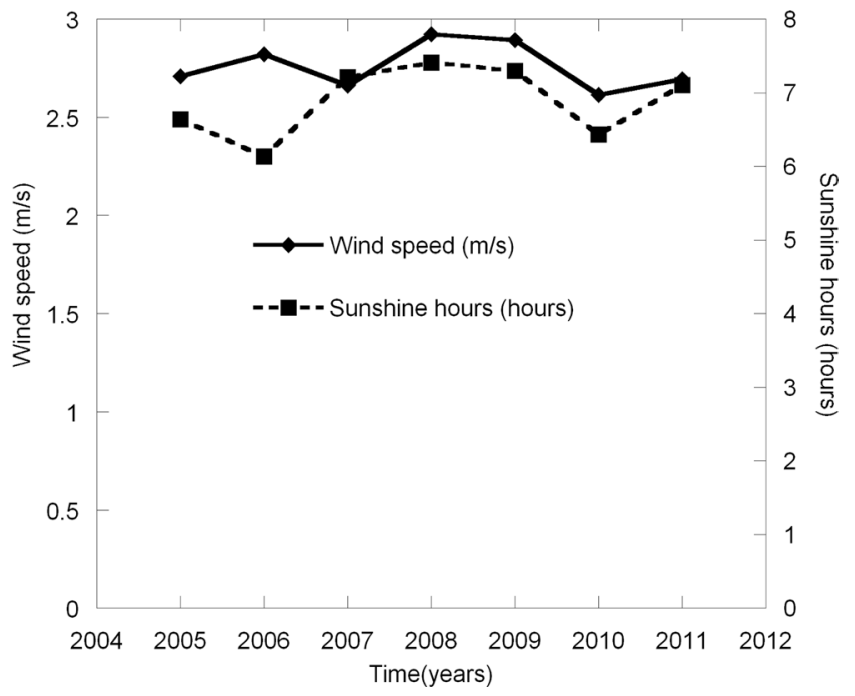

(c)

Figure 1. Annual variation of meteorological factors in the study area.

carbon release, with the rate of $0.030-0.039 \mathrm{mg} \mathrm{CO} / 2 \mathrm{~m}^{2} \cdot \mathrm{s}$ and the mean value $0.033 \mathrm{mg} \mathrm{CO} / 2 \mathrm{~m}^{2} \cdot \mathrm{s}$. The maximum half-hour $\mathrm{CO}_{2}$ release ranged from 0.343 to $0.621 \mathrm{mg} \mathrm{CO} / \mathrm{m}^{2} \cdot \mathrm{s}$, with the mean value $0.485 \mathrm{mg} \mathrm{CO} / \mathrm{m}^{2} \cdot \mathrm{s}$. Because weeds of ten occurred during the transition stage between non-growing season and growing season, the $\mathrm{CO}_{2}$ was assimilated with the maximum rate of $0.102-0.597$ $\mathrm{mg} \mathrm{CO} / \mathrm{m}^{2} \cdot \mathrm{s}$ and the mean value $0.363 \mathrm{mg} \mathrm{CO} / \mathrm{m}^{2} \cdot \mathrm{s}$ (Figure 2). In one year, the non-growing season was divided into spring and winter non-growing seasons. The amount of $\mathrm{CO}_{2}$ release during spring and winter fluctuated about $300 \mathrm{~g}$ $\mathrm{CO}_{2} / \mathrm{m}^{2}$, e.g., the mean total $\mathrm{CO}_{2}$ release in winter and spring non-growing season were 337.16 and $273.76 \mathrm{~g} \mathrm{CO}_{2} / \mathrm{m}^{2}$, respectively (Figure 3). The carbon release in non-growing season varied between 153.16 and $202.13 \mathrm{~g} \mathrm{C} / \mathrm{m}^{2}$ with the mean value $168.59 \mathrm{~g} \mathrm{C} / \mathrm{m}^{2}$ from 2005 to 2011 (Table 1).

\subsubsection{NEE in Growing Season}

The $\mathrm{CO}_{2}$ exchange in growing season from 2005 to 2011 was shown as carbon 


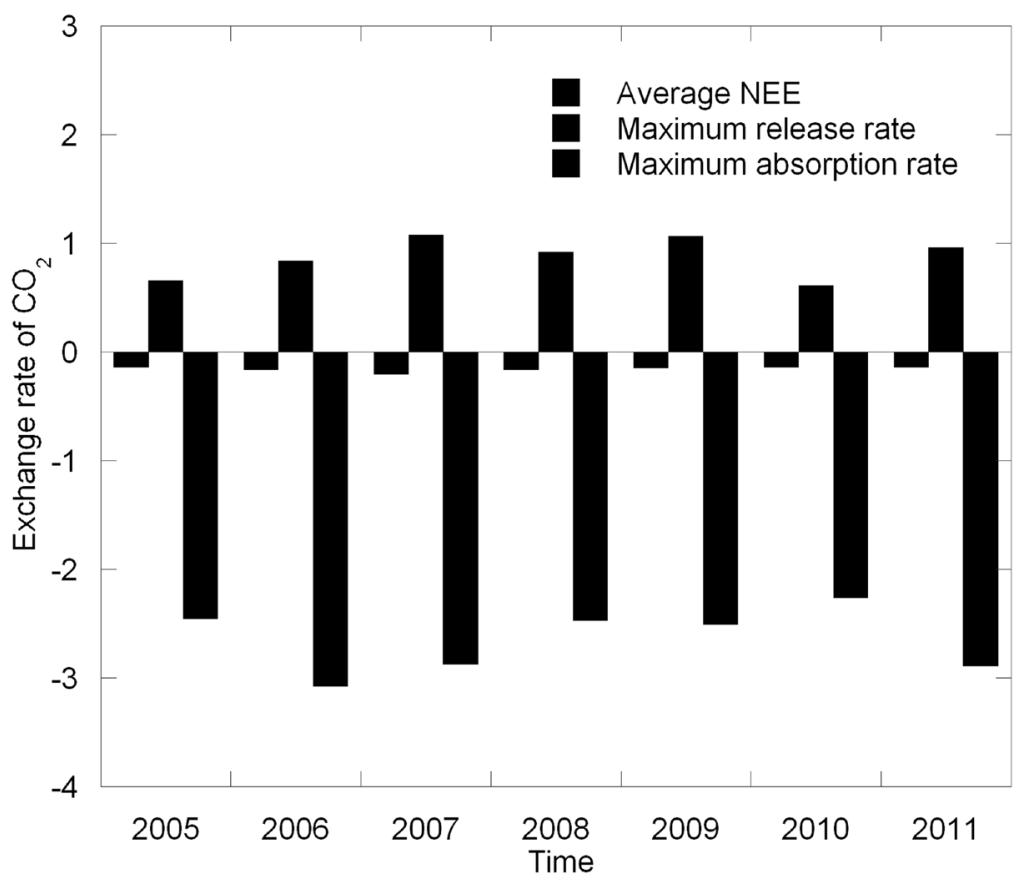

Figure 2. Half-hour NEE rate in non-growing season of maize from 2005 to 2011.

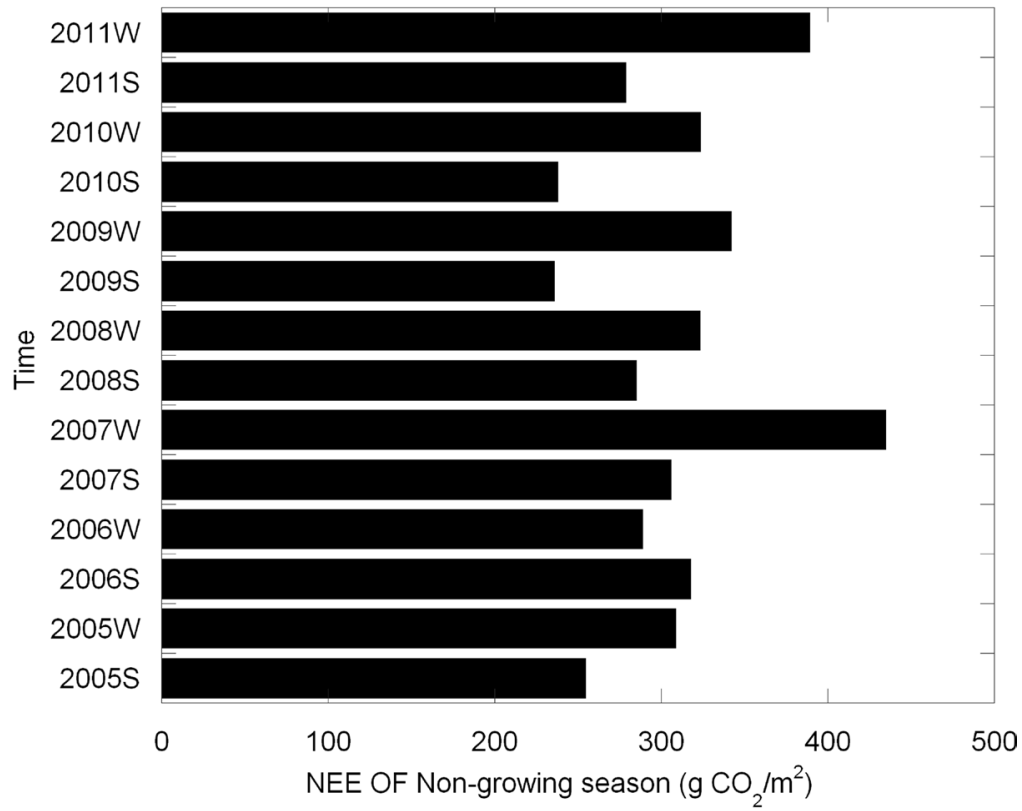

Figure 3. Total NEE in non-growing season of maize. W: winter; S: spring.

assimilation, with the fluctuating rate between -0.138 and $-0.202 \mathrm{mg} \mathrm{CO} / \mathrm{m}^{2} \cdot \mathrm{s}$. The maximum and minimum values occurred in 2007 and 2010, respectively. The average annual $\mathrm{CO}_{2}$ assimilating rate was $-0.158 \mathrm{mg} \mathrm{CO} / \mathrm{m}^{2} \cdot$ s. For day timescale, the $\mathrm{CO}_{2}$ budget was shown as carbon release at night and assimilation in the day time. The maximum value of $\mathrm{CO}_{2}$ release varied between 0.061 and $1.079 \mathrm{mg} \mathrm{CO} / 2 \mathrm{~m}^{2} \cdot \mathrm{s}$, with the average annual value of $0.875 \mathrm{mg} \mathrm{CO} / \mathrm{m}^{2} \cdot \mathrm{s}$. The maximum value of $\mathrm{CO}_{2}$ assimilation ranged from -2.261 to $-3.078 \mathrm{mg} \mathrm{CO} / \mathrm{m}^{2} \cdot \mathrm{s}$, with the average annual value of $-2.641 \mathrm{mg} \mathrm{CO} / \mathrm{m}^{2} \cdot \mathrm{s}$ (Figure 4). From 2005 to 
Table 1. Carbon content in maize grain and NEE of annual, non-growing season and growing season in maize agricultural ecosystem.

\begin{tabular}{cccccc}
\hline & $\begin{array}{c}\text { NEE of annual } \\
\left(\mathrm{g} \mathrm{C} / \mathrm{m}^{2}\right)\end{array}$ & $\begin{array}{c}\text { NEE of growing season } \\
\left(\mathrm{g} \mathrm{C} / \mathrm{m}^{2}\right)\end{array}$ & $\begin{array}{c}\text { NEE of non-growing season } \\
\left(\mathrm{g} \mathrm{C} / \mathrm{m}^{2}\right)\end{array}$ & $\begin{array}{c}\text { Carbon content of the grain } \\
\left(\mathrm{g} \mathrm{C} / \mathrm{m}^{2}\right)\end{array}$ & $\begin{array}{c}\text { Carbon content of others } \\
\left(\mathrm{g} \mathrm{C} / \mathrm{m}^{2}\right)\end{array}$ \\
\hline 2005 & -334.61 & -488.21 & 153.60 & -283.29 & -51.32 \\
2006 & -385.49 & -551.02 & 165.53 & -339.94 & -45.55 \\
2007 & -487.33 & -689.36 & 202.03 & -334.26 & -153.07 \\
2008 & -418.33 & -584.20 & 165.87 & -324.45 & -93.88 \\
2009 & -354.34 & -511.99 & 157.65 & -311.59 & -42.75 \\
2010 & -335.01 & -488.17 & 153.16 & -226.60 & -108.41 \\
2011 & -316.96 & -499.28 & 182.32 & -284.13 & -32.83 \\
Average & -376.01 & -544.61 & 168.59 & -300.61 & -75.40 \\
Total & -2632.07 & -3812.23 & 1180.16 & 2104.26 & -527.812 \\
\hline
\end{tabular}

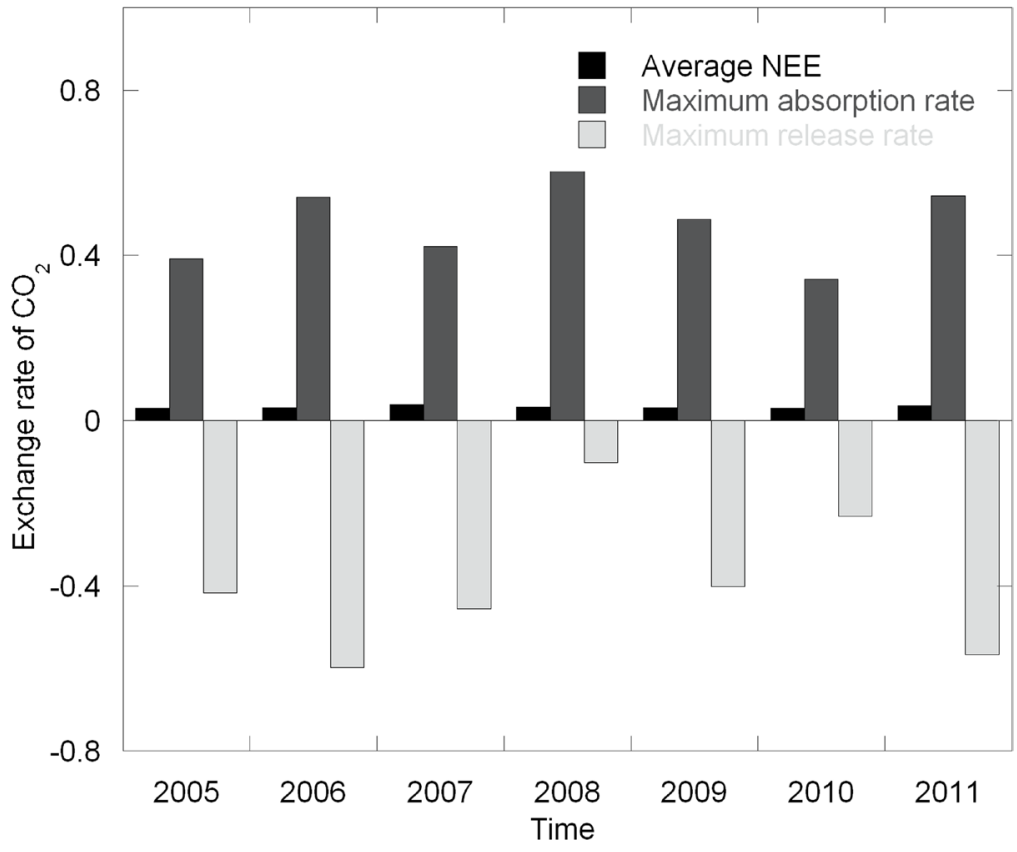

Figure 4. Half-hour NEE rate in growing season of maize from 2005 to 2011.

2011, carbon assimilation in growing season varied as a single peak curve, i.e., the value tended to first increase and then decrease, likely related to annual meteorological conditions. The value of carbon assimilation in growing season in 2005-2011 ranged from -488.17 to $-689.36 \mathrm{~g} \mathrm{C} / \mathrm{m}^{2}$, with the average annual value of $-544.61 \mathrm{~g} \mathrm{C} / \mathrm{m}^{2}$ (Table 1 ).

During the process of maize growth, the $\mathrm{CO}_{2}$ flux represented $\mathrm{CO}_{2}$ release from sowing to seven leaf stages. The $\mathrm{CO}_{2}$ exchange rates from sowing to emergence, emergence to three leaf and three leaf to seven leaf stages were $0.032 \mathrm{mg} \mathrm{CO} / 2 \mathrm{~m}^{2} \cdot \mathrm{s}$, $0.032 \mathrm{mg} \mathrm{CO} / 2 \mathrm{~m}^{2} \cdot \mathrm{s}$ and $0.022 \mathrm{mg} \mathrm{CO} / \mathrm{m}^{2} \cdot \mathrm{s}$, respectively. From seven leaf stage to mature, $\mathrm{CO}_{2}$ was assimilated with a single peak curve of assimilating rate. The maximum value of $-0.374 \mathrm{mg} \mathrm{CO} / \mathrm{m}^{2} \cdot \mathrm{s}$ occurred during flowering to milking stages, and there was the maximum fluctuation in this period (Figure 5). 


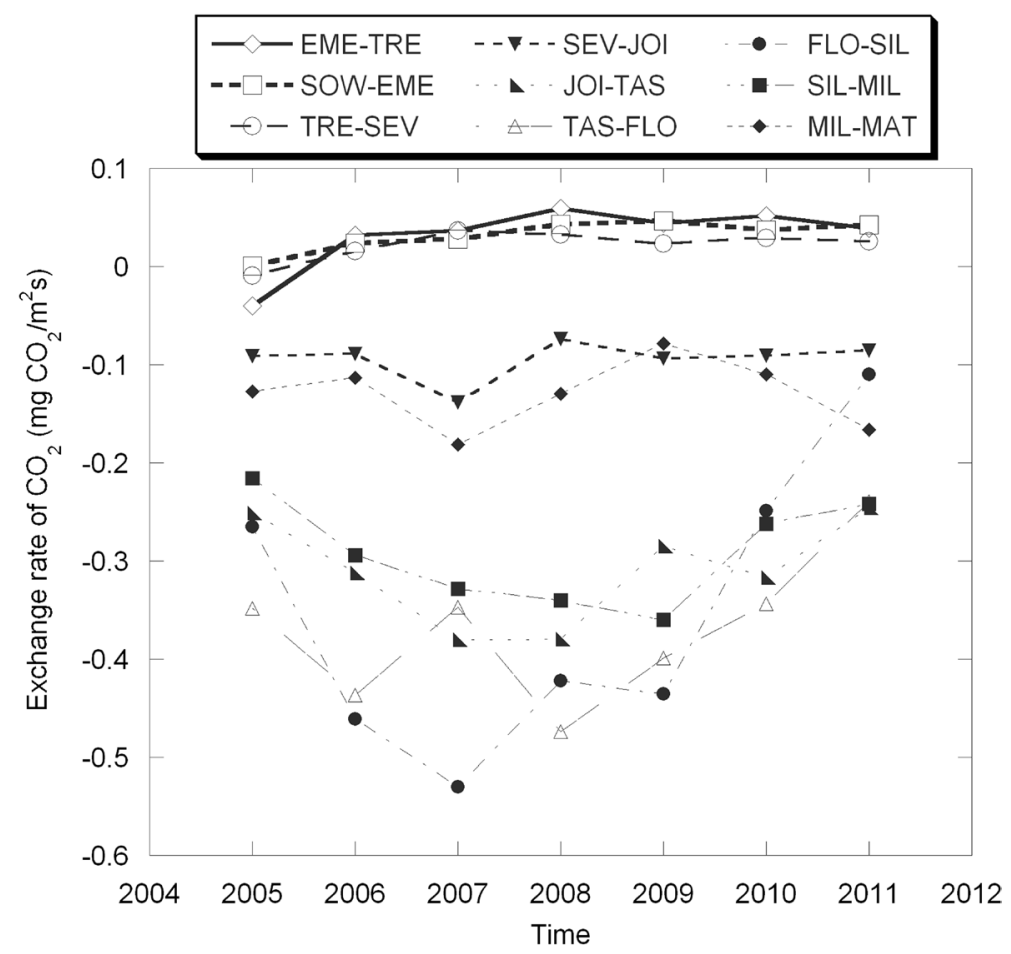

Figure 5. NEE rate at different development stages of maize from 2005 to 2011.

\subsubsection{Annual NEE}

The NEE showed carbon assimilation during growing season and carbon release during non-growing season, furthermore; carbon assimilating rate was far greater than carbon release rate. The $\mathrm{CO}_{2}$ release in growing season might be resulted from continuous rainy weather. During growing season, carbon assimilation appeared as a single peak curve with the maximum in July and the minimum in both early May and late September. During non-growing season, $\mathrm{CO}_{2}$ release was characterized by small shake (Figure 6). Carbon budget in rain-fed maize agricultural ecosystem was characterized by carbon sinks from 2005 to 2011, and annual carbon sink varied between -316.96 and $-487.33 \mathrm{~g} \mathrm{C} / \mathrm{m}^{2}$ and the average annual value was $-367.01 \mathrm{~g} \mathrm{C} / \mathrm{m}^{2}$ (Table 1 ).

\subsection{NEE Regulation}

\subsubsection{Meteorological Regulation}

The key factor influencing NEE in non-growing season was air temperature. Especially, the lowest air temperature was significantly correlated to NEE with the correlation coefficient of $0.72(P<0.05)$. The higher the lowest air temperature was, the more the NEE was. In growing season, the main meteorological factors affecting NEE included the maximum air temperature, vapor pressure deficit (VPD) and sun hours. As for annual NEE, the most important affecting factor was mean air temperature $(R=-0.81, P<0.05)$, followed by VPD $(R=-0.64, P<$ 0.1 ). During maize reproductive growth, the NEE was significantly affected by meteorological factors, especially the air temperature, VPD, sun hours and precipitation (Table 2). 


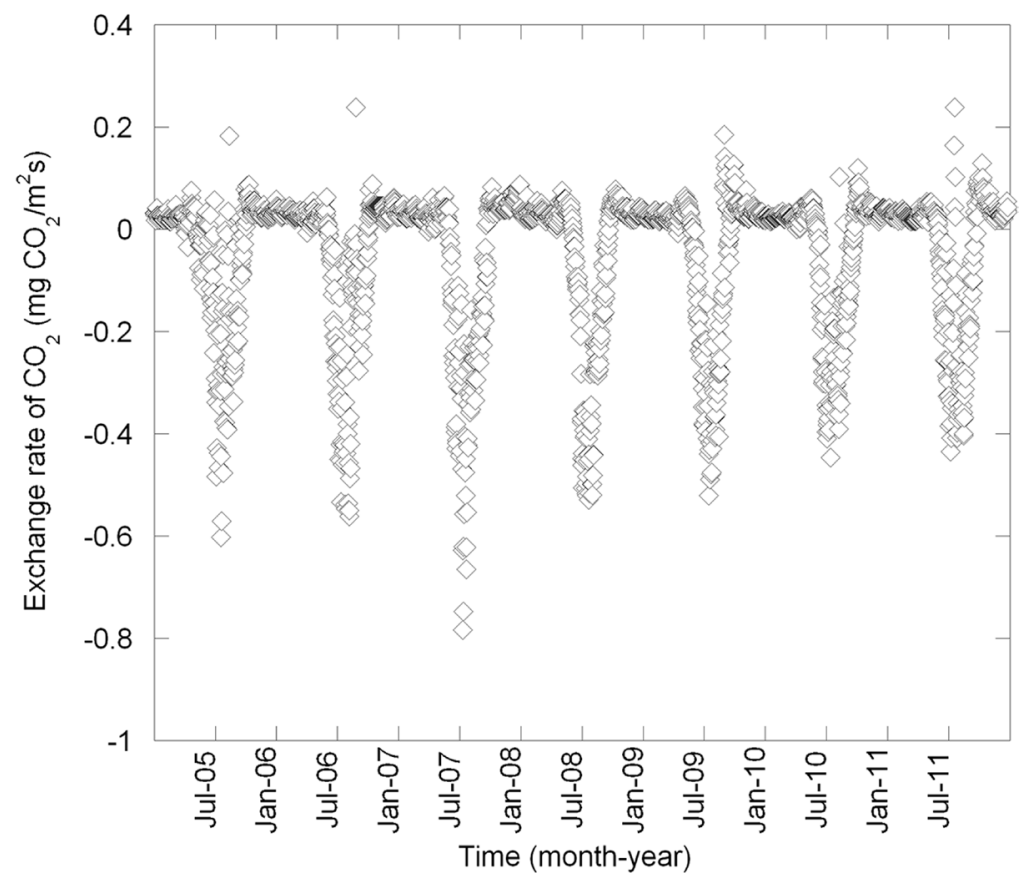

Figure 6. Daily mean NEE rate over maize agricultural ecosystem from 2005 to 2011 .

Table 2. Relationship between meteorological factors and exchange rate of NEE at different development stage of maize.

\begin{tabular}{|c|c|c|c|c|c|c|c|c|c|}
\hline & Rainfall & $\begin{array}{l}\text { Average air } \\
\text { pressure } \\
\text { (pa) }\end{array}$ & $\begin{array}{c}\text { Average air } \\
\text { temperature } \\
\left({ }^{\circ} \mathrm{C}\right)\end{array}$ & $\begin{array}{c}\text { Average } \\
\text { water } \\
\text { pressure (pa) }\end{array}$ & $\begin{array}{c}\text { Average } \\
\text { relative } \\
\text { humidity }(\%)\end{array}$ & $\begin{array}{l}\text { Average saturated } \\
\text { vapor pressure } \\
\text { deficit (pa) }\end{array}$ & $\begin{array}{c}\text { Average } \\
\text { sunshine } \\
\text { hours (hours) }\end{array}$ & $\begin{array}{c}\text { Minimum } \\
\text { air temperature } \\
\left({ }^{\circ} \mathrm{C}\right)\end{array}$ & $\begin{array}{c}\text { Maximum } \\
\text { air temperature } \\
\left({ }^{\circ} \mathrm{C}\right)\end{array}$ \\
\hline SOW-EME & 0.38 & 0.30 & -0.29 & -0.13 & -0.01 & -0.12 & -0.27 & -0.31 & -0.29 \\
\hline EME-TRE & $-0.94^{* * *}$ & -0.28 & 0.25 & 0.05 & -0.12 & 0.16 & 0.48 & -0.22 & 0.34 \\
\hline TRE-SEV & -0.42 & -0.04 & -0.17 & -0.49 & -0.26 & 0.17 & 0.19 & -0.52 & 0.07 \\
\hline SEV-JOI & 0.53 & 0.28 & 0.06 & -0.20 & -0.12 & 0.18 & -0.40 & 0.29 & 0.12 \\
\hline JOI-TAS & -0.37 & -0.39 & -0.15 & -0.35 & -0.19 & 0.12 & 0.19 & -0.22 & -0.03 \\
\hline TAS-FLO & 0.35 & -0.25 & -0.54 & 0.54 & $0.84^{\star *}$ & $-0.86^{\star *}$ & $-0.87^{\star *}$ & -0.02 & -0.68 \\
\hline FLO-SIL & -0.07 & -0.23 & -0.13 & 0.33 & 0.48 & -0.44 & -0.40 & 0.25 & -0.38 \\
\hline SIL-MIL & $0.79^{\star}$ & -0.42 & -0.60 & 0.61 & $0.84^{\star *}$ & $-0.85^{\star *}$ & $-0.73^{*}$ & 0.03 & $-0.81^{\star}$ \\
\hline MIL-MAT & 0.60 & -0.18 & -0.58 & 0.15 & 0.45 & -0.52 & -0.65 & -0.24 & -0.61 \\
\hline $\begin{array}{l}\text { Growing } \\
\text { season }\end{array}$ & 0.17 & 0.30 & -0.53 & 0.63 & 0.65 & $-0.73^{*}$ & -0.61 & 0.19 & $-0.89^{* *}$ \\
\hline $\begin{array}{l}\text { Non-growing } \\
\text { season }\end{array}$ & g -0.28 & 0.52 & 0.65 & 0.44 & 0.28 & 0.19 & 0.02 & $0.72^{*}$ & 0.54 \\
\hline Annual & 0.13 & 0.15 & $-0.81^{\star}$ & 0.49 & 0.16 & -0.64 & -0.32 & -0.65 & $-0.77^{\star}$ \\
\hline
\end{tabular}

Notes: ${ }^{*}: P<0.05 ;{ }^{* *}: P<0.01 ;{ }^{* *}: P<0.001$. Development stage: SOW-EME: Sow seed to seedling emergence; EME-TRE: Seedling emergence to trefoil; TRE-SEV: Trefoil to seven leaf; SEV-JOI: Seven leaf to joint; JOI-TAS: Joint to tassel; TAS-FLO: Tassel to flower; FLO-SIL: Flower to silk; SIL-MIL: Silk to milk; MIL-MAT: Milk to mature.

\subsubsection{Biological Regulation}

There was a significant influence of maize leaf area index (LAI) on NEE. When PAR changed little, $\mathrm{CO}_{2}$ assimilating rate increased with LAI. For example, when PAR was $400-600 \mu \mathrm{mol} / \mathrm{m}^{2} \cdot \mathrm{s}, 600-800 \mu \mathrm{mol} / \mathrm{m}^{2} \cdot \mathrm{s}, 800-1000 \mu \mathrm{mol} / \mathrm{m}^{2} \cdot \mathrm{s}$ and 
more than $1000 \mu \mathrm{mol} / \mathrm{m}^{2} \cdot \mathrm{s}$, the squared correlation coefficient between NEE and LAI were $0.997(P<0.001), 0.956(P<0.001), 0.961(P<0.001)$ and $0.985(P<$ $0.001)$, respectively. At these four levels of PAR, the slopes of linear functions between NEE and LAI were $-0.0237,-0.0816,-0.0935$ and -0.1957 , respectively (Figure 7), indicating that variation extent of $\mathrm{CO}_{2}$ assimilation was caused by LAI. Therefore, the more the PAR was, the stronger effect of LAI on the NEE was.

Total amount of carbon budget during growing season was determined by time length of maize development stage. The relationships between NEE had a positive related with days of growing season $(R=0.63)$, days from sowing to seven leaf stage $(R=0.58)$, and a negative related with days from seven leaf to mature stage $(R=0.37)$, indicating that the longer the growing season and the time from sowing to seven leaf stage were, the less the $\mathrm{CO}_{2}$ assimilation was, and the longer the time from seven leaf to mature stage was, the more the $\mathrm{CO}_{2}$ assimilation was.
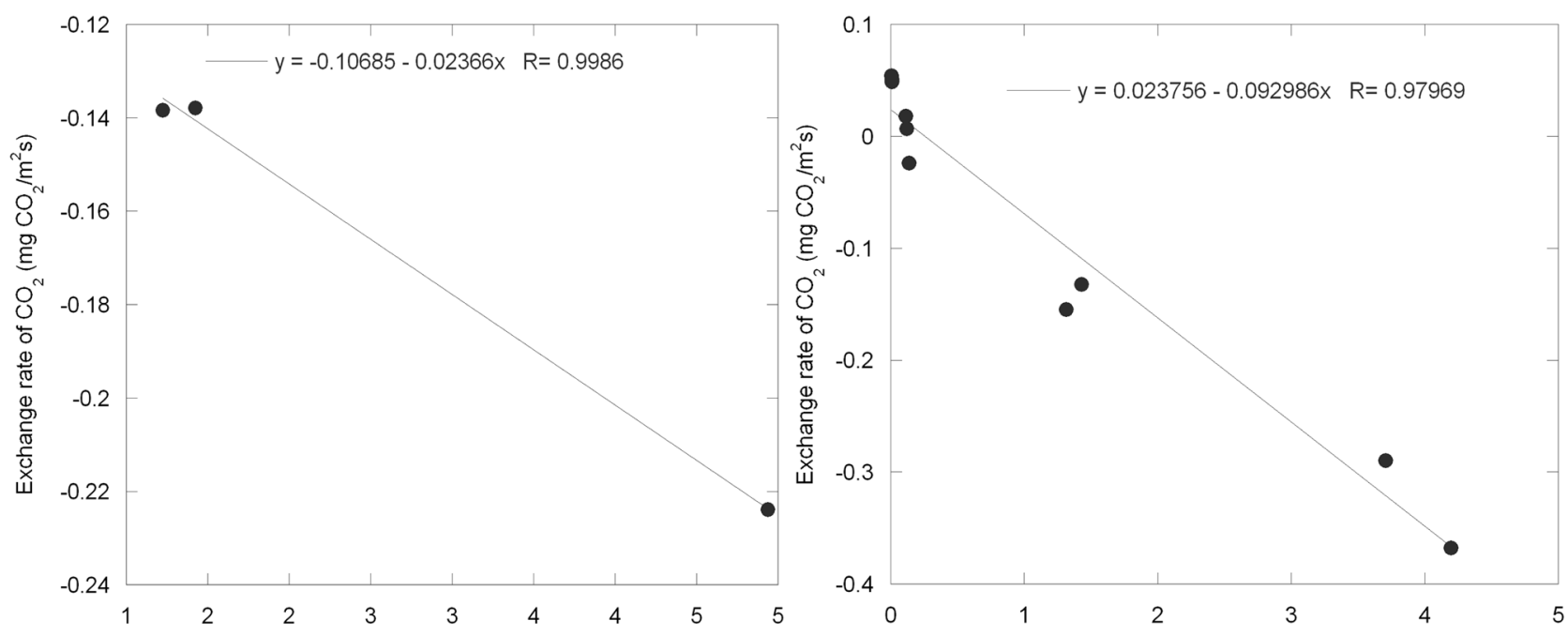

(a) (b)
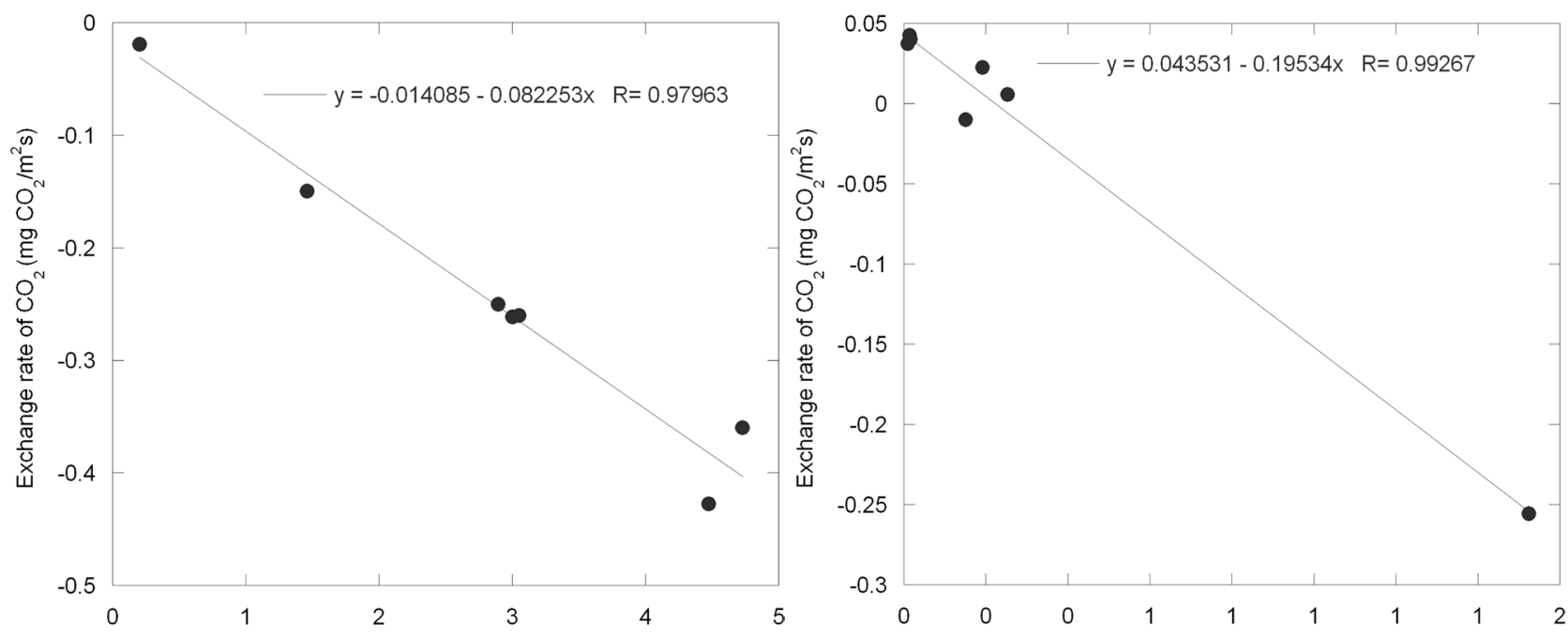

(c) (d)

Figure 7. Relationship between leaf area index and NEE under different PAR levels in maize agricultural ecosystem. The grading of mean PAR from 8:00 am to 4:00 pm: (a): $400-600 \mu \mathrm{mol} / \mathrm{m}^{2} \cdot \mathrm{s},(\mathrm{b}): 600-800 \mu \mathrm{mol} / \mathrm{m}^{2} \cdot \mathrm{s}$, (c): $800-1000 \mu \mathrm{mol} / \mathrm{m}^{2} \cdot \mathrm{s},(\mathrm{d}):>1000$ $\mu \mathrm{mol} / \mathrm{m}^{2} \cdot \mathrm{s}$. 
Therefore, the growing season was extended owing to the prolonged time from sowing to seven leaf stage so that the NEE during growing season decreased. The sowing stage was negatively correlated with the NEE during the growing season, i.e., the earlier the sowing was, the longer the early stage of maize development was, and the function of carbon sink was weaken.

\section{Discussion}

During non-growing season, the mean and range of NEE in rain-fed maize agricultural ecosystem in Northeast China were $168.59 \mathrm{~g} \mathrm{C} / \mathrm{m}^{2}$ and 153.16 $202.03 \mathrm{~g} \mathrm{C} / \mathrm{m}^{2}$, respectively, slightly lower than in the rain-fed maize in Nebraska $\left(170-255 \mathrm{~g} \mathrm{C} / \mathrm{m}^{2}\right)$ [4]. During growing season, the mean and range of NEE were -544.61 and $-689.36--488.17 \mathrm{~g} \mathrm{C} / \mathrm{m}^{2}$, respectively, higher than that over summer maize in Yucheng $\left(-165.6 \mathrm{~g} \mathrm{C} / \mathrm{m}^{2}\right.$ and $\left.-120.1 \mathrm{~g} \mathrm{C} / \mathrm{m}^{2}\right)$ [8], rice in Sanjiang plain $\left(-530 \mathrm{~g} \mathrm{C}^{\mathrm{m}} \mathrm{m}^{2}\right)$ [22], and winter wheat in Anhui $\left(-326.87 \mathrm{~g} \mathrm{C} / \mathrm{m}^{2}\right)$ [23]. For annual NEE, the mean and range of NEE were $-376.01 \mathrm{~g} \mathrm{C} / \mathrm{m}^{2}$ and -316.96 $-487.33 \mathrm{~g} \mathrm{C} / \mathrm{m}^{2}$, respectively, higher than in forest ecosystems in temperate zone, such as Harvest forest $\left(-200 \mathrm{~g} \mathrm{C} / \mathrm{m}^{2}\right)$ [24], Howland forest $\left(-174 \mathrm{~g} \mathrm{C} / \mathrm{m}^{2}\right)$ [25] and Changbai mountains $\left(-169--187 \mathrm{~g} \mathrm{C} / \mathrm{m}^{2}\right)$ [26], but lower than in subtropical forests, such as Dinghu mountain $\left(-441.2--563 \mathrm{~g} \mathrm{C} / \mathrm{m}^{2}\right)$ [27] and Qinanyanzhou ( $\left.-553--645 \mathrm{~g} \mathrm{C} / \mathrm{m}^{2}\right)$ [28]. The average annual NEE in the present study was much higher than in grassland ecosystem, such as tall grass steppe $\left(-50--275 \mathrm{~g} \mathrm{C} / \mathrm{m}^{2}\right)$ [11], temperate grassland $\left(18--20 \mathrm{~g} \mathrm{C} / \mathrm{m}^{2}\right)$ [29], and Mediterranean grassland $\left(30--130 \mathrm{~g} \mathrm{C} / \mathrm{m}^{2}\right)$ [30].

In the present study, the mean rate of $\mathrm{CO}_{2}$ release was $0.033 \mathrm{mg} \mathrm{CO} / \mathrm{m}^{2} \cdot \mathrm{s}$ during non-growing season from 2005 to 2011. Carbon release could be decreased by $2.85 \mathrm{~g} \mathrm{CO}_{2} / \mathrm{m}^{2} \cdot \mathrm{d}$ due to shortening non-growing season. The mean rate of $\mathrm{CO}_{2}$ assimilation during growing season was $-0.158 \mathrm{mg} \mathrm{CO} / \mathrm{m}^{2} \cdot \mathrm{s}, 5$ times higher than during non-growing season. The variation of NEE in each development stage of maize was quite large. For example, from sowing to three leaf stage of about 36 days, the carbon budget appeared $\mathrm{CO}_{2}$ release with the rate of $0.029 \mathrm{mg} \mathrm{CO} / \mathrm{m}^{2} \cdot \mathrm{s}$, which was consistent with the result that there is $\mathrm{CO}_{2}$ absorption in maize ecosystem after 30 - 35 days of sowing [4]. The absorption rate exponentially increased from seven leaf to flowering stage and reached the maximum value of $-0.375 \mathrm{mg} \mathrm{CO} / \mathrm{m}^{2}$.s. From flowering to mature stage, the $\mathrm{CO}_{2}$ absorption rate gradually decreased and reached the minimum value of -0.125 $\mathrm{mg} \mathrm{CO} / \mathrm{m}^{2} \cdot \mathrm{s}$ in mature stage. The period of $\mathrm{CO}_{2}$ absorption was from seven leaf to mature stage of an average of 112 days. Therefore, the effects of the extension at different development stages on the NEE are various. Although the time length of $\mathrm{CO}_{2}$ release was two times longer than that of $\mathrm{CO}_{2}$ absorption, the annual $\mathrm{CO}_{2}$ exchange was characterized by carbon sink. This carbon was changed into grain production of maize. The carbon content of the grain production ranged between -226.6 and $-339.94 \mathrm{~g} \mathrm{C} / \mathrm{m}^{2}$, with the mean value of $300.61 \mathrm{~g}$ $\mathrm{C} / \mathrm{m}^{2}$ (Table 1), which was slightly lower than that in non-tillage maize agricultural ecosystem in USA $\left(-392.0 \mathrm{~g} \mathrm{C} / \mathrm{m}^{2}\right)$. Except for the grain production, the 
mean $\mathrm{CO}_{2}$ exchange was $-75.4 \mathrm{~g} \mathrm{C} / \mathrm{m}^{2}$, characterized by carbon sink. The harvest index in ecosystem was $0.554 \pm 0.058$ slightly more than the value raised by Hollinger et al. (2005) [1].

Temperature is an important factor affecting the carbon balance of terrestrial ecosystems [31] [32]. In the present study, we found that air temperature significantly affected carbon balance of maize agricultural ecosystem, and especially the highest air temperature was positively correlated with carbon budget in both growing season and total one year $(P<0.05)$. The highest air temperature reflects temperature condition in daytime during growing season, and has direct effects on plant photosynthesis. The higher the daytime temperature is, the stronger photosynthetic rate is. Generally, higher VPD may cause stoma to close. Therefore, VPD reflects, to a certain extent, the ability of ecosystem carbon budget. For example, in the forest ecosystem, VPD can explain about $45 \%$ variation of carbon exchange [26]. At ecosystem level, when VPD is less than $1 \mathrm{kPa}$, gross ecosystem productivity (GEP) will rise with increasing VPD; but when VPD is greater than $1 \mathrm{kPa}, \mathrm{GEP}$ decreased with rising VPD [33]. VPD had significant impact on carbon exchange in rain-fed maize agricultural ecosystem of this study. At annual level, NEE increased with rising VPD, which meant VPD was less than $1 \mathrm{kPa}$. The length of photosynthetic time is mirrored by sunshine duration. The longer the sunshine duration is, the more the $\mathrm{CO}_{2}$ absorption is. Therefore, the climate warming may enhance carbon absorption capacity in growing season and result in the increase of carbon release in non-growing season and annual carbon sequestration. For example, years of 2007 and 2008 with higher mean annual air temperatures showed higher NEE. The rainfall can affect NEE over rain-fed maize agricultural ecosystem. Such as, in the late development stage, the positive correlation between rainfall and NEE appeared much stronger, indicating that the increase of precipitation caused the decreasing NEE. When the precipitation was in the range of $400-800 \mathrm{~mm}$ during the growing season, the $\mathrm{CO}_{2}$ absorption decreased with the rise of rainfall. Air temperature and precipitation in 2008 were higher than in 2007 (Figure 1(a) and Figure 1(b)), therefore, NEE in 2007 was much more than in 2008 (Table 1). In recent years, the climate tended to be warmer and drier in Northeast China [5]. This trend of climate could lead to the increase of carbon sink in rain-fed maize agricultural ecosystem in Northeast China.

Photosynthetic active radiation and leaf area index were two key biological factors affecting plant photosynthesis. The response intensity of photosynthesis rate to leaf area index increased with increasing PAR. Therefore, in the late period of growing season, the amount of PAR determined NEE of agricultural ecosystem. For example, during the period from seven-leaf to mature stage, long-time continuous overcast and rainy days could cause the sharp decline of annual $\mathrm{CO}_{2}$ absorption. The advance of sowing can lengthen the early stage of maize development so that it cannot increase $\mathrm{CO}_{2}$ absorption during growing season. Therefore, how to make clear the development period of maize in response to climate change is helpful to better assess the carbon budget of maize 
responding to climate change.

\section{Conclusion}

This study revealed carbon budget characteristics in non-growing season, growing season and annual based on the eddy-covariance observation data during 2005-2011. These conditions fluctuate from year to year and can cause the variety of carbon sink capacity. The proportion of the carbon budget in the growing season transformed into carbon content of maize grain yield was determined. The result provides a technical method for carbon budget assessment of warm temperate rain-fed maize ecosystem. The characteristics of carbon budget in different growth stages of maize were determined. There are carbon source in the maize seedling stage and the carbon sink in the middle and growth stage of maize. The differences of daily average temperature and saturated vapor pressure are the key factors affecting the carbon budget in maize fields.

\section{Acknowledgements}

This work was supported by the National Natural Science Foundation of China (41330531). We gratefully acknowledge work assistance in the Flux station of Jinzhou Meteorology Bureau.

\section{References}

[1] Hollinger, S.E., Bernacchi, C.J. and Meyers, T.P. (2005) Carbon Budget of Mature No-Till Ecosystem in North Central Region of the United States. Agricultural and Forest Meteorology, 130, 59-69. https://doi.org/10.1016/j.agrformet.2005.01.005

[2] Caldeira, K., Morgan, M.G., Baldocchi, D., Brewer, P.G., Chen, C.T.A., Nabuurs, G.J., Nakicenovic, N. and Robertson, G.P. (2004) A Portfolio of Carbon Management Options. In: Field, C.B. and Raupach, M.R., Eds., The Global Carbon Cycle, Island Press, Washington DC, 103-109.

[3] Wood, S., Sebastian, K. and Scherr, S.J. (2000) Pilot Analysis of Global Ecosystems: Agroecosystems. Report, World Resources Institute, Washington DC.

[4] Verma, S.B., Dobermann, A., Cassman, K.G., Walters, D.T. and Knops, J.M.N. (2005) Annual Carbon Dioxide Exchange in Irrigated and Rained Maize-Based Agr-Ecosystems. Agricultural and Forest Meteorology, 131, 77-96. https://doi.org/10.1016/j.agrformet.2005.05.003

[5] Sun, F.H., Yang, S.Y. and Chen, P.S. (2005) Climatic Warming-Drying Trend in Northeastern China during the Last 44 Years and Its Effects. Chinese Journal of Ecology, 24, 751-755.

[6] Moors, E.J., Jacobs, C.M.J., Jans, W., Supit, I., Bernhofer, C., Buchman, N., Carrara, A., Ceschia, E., Elbers, J., Eugster, W., Kruijt, B., Kutsch, W., Loubet, B., Magliulo, E., Moureaux, C., Olioso, A., Saunders, M. and Søgaard, H. (2010) Variability in Carbon Exchange of European Croplands. Agriculture, Ecosystems and Environment, 139, 325-335. https://doi.org/10.1016/j.agee.2010.04.013

[7] Moureaux, C., Debacq, A., Bodson, B., Heinisch, B. and Aubinet, M. (2006) Annual Net Ecosystem Exchange by a Sugar Beet Crop. Agriculture, Ecosystems and Environment, 139, 25-39. https://doi.org/10.1016/j.agrformet.2006.05.009

[8] Li, J., Yu, Q., Sun, X.M., Tong, X.J., Ren, C.Y., Wang, J., Liu, A.M., Zhu, Z.L. and Yu, G.R. (2006) Carbon Dioxide Exchange and the Mechanism of Environmental 
Control in a Farmland Ecosystem in North China Plain. Science in China Series D-Earth Sciences, 36, 210-223. https://doi.org/10.1007/s11430-006-8226-1

[9] Suyker, A.E., Verma, S.B., Burba, G.G., Arkebauer, T.J., Walters, D.T. and Hubbard, K.G. (2004) Growing Season Carbon Dioxide Exchange in Irrigated and Rainfed Maize. Agricultural and Forest Meteorology, 124, 1-13. https://doi.org/10.1016/j.agrformet.2004.01.011

[10] Baker, J.M. and Griffis, T.J. (2005) Examining Strategies to Improve the Carbon Balance of Corn/Soybean Agriculture Using Eddy Covariance and Mass Balance Techniques. Agricultural and Forest Meteorology, 128, 163-177.

[11] Suyker, A.E., Verma, S.B. and Burba, G.G. (2003) Interannual Variability in Net CO2 Exchange of a Native Tallgrass Prairie. Global Change Biology, 9, 1-11. https://doi.org/10.1046/j.1365-2486.2003.00567.x

[12] Gervois, S., Ciais, P., de Noblet-Ducoudré, N., Brisson, N., Vuichards, N. and Viovy, N. (2008) Carbon and Water Balance of European Croplands throughout the 20th Century. Global Biogeochemical Cycles, 22, p 13. https://doi.org/10.1029/2007GB003018

[13] Bavin, T.K., Griffis, T.J., Baker, J.M. and Venterea, R.T. (2009) Impact of Reduced Tillage and Cover Cropping on the Greenhouse Gas Budget of a Maize/Soybean Rotation System. Agriculture, Ecosystems and Environment, 134, 234-242. https://doi.org/10.1016/j.agee.2009.07.005

[14] Han, G., Zhou, G., Xu, Z., Yang, Y., Liu, J. and Shi, K. (2007) Soil Temperature and Biotic Factors Drive the Seasonal Variation of Soil Respiration in a Maize (Zea Mays L.) Agricultural Ecosystem. Plant Soil, 291, 15-26. https://doi.org/10.1007/s11104-006-9170-8

[15] Moureaux, C., Debacq, A., Hoyaux, J., Suleau, M., Tourneur, D., Vancutsem, F., Bodson, B. and Aubinet, M. (2008) Carbon Balance Assessment of a Belgian Winter Wheat Crop (Triticum Aestivum L.). Global Change Biology, 4, 1-14. https://doi.org/10.1111/j.1365-2486.2008.01560.x

[16] Baldocchi, D.D., Falge, E., Gu, L., Olsen, R., Hollinger, D., Running,S., Anthoni, P., Bernhofer, C., Davis, K., Evans, R., Fuentes, J., Goldstein, A., Katul, G., Law, B., Lee, X., Malhi, Y., Meyers, T., Munger, W., Oechel, W., Paw, U.K.T., Pilegaard, K., Schmid, H.P., Valentini, R., Verma, S., Vesala, T., Wilson, K. and Wofsy, S. (2001) FLUXNET: A New Tool to Study the Temporal and Spatial Variability of Ecosystem-Scale Carbon Dioxide, Water Vapor, and Energy Balance Densities. Bulletin of the American Meteorological Society, 82, 2415-2434. https://doi.org/10.1175/1520-0477(2001)082<2415:FANTTS $>2.3 . C O ; 2$

[17] Mauder, M., Foken, T., Clement, R. and Elbers, J.A. (2008) Quality Control of CarboEurope Flux Data: Inter-Comparison of Eddy-Covariance Software. Biogeosciences, 5, 451-462. https://doi.org/10.5194/bg-5-451-2008

[18] Vickers, D. and Mahrt, L. (1997) Quality Control and Flux Sampling Problems for Tower and Aircraft Data. Journal of Atmospheric and Oceanic Technology, 14, 512-526. https://doi.org/10.1175/1520-0426(1997)014<0512:QCAFSP >2.0.CO;2

[19] Kaimal, J.C. and Finnigan, J.J. (1994) Atmospheric Boundary Layer Flows. Oxford University Press, Oxford.

[20] Webb, E.K., Pearman, G.I. and Leuning, R. (1980) Correction of Flux Measurements for Density Effects Due to Heat and Water Vapour Transfer. Journal of Atmospheric and Oceanic Technology, 106, 85-100. https://doi.org/10.1002/qj.49710644707

[21] Falge, E., Baldocchi, D., Olson, R., Anthoni, P., Aubinet, M., Bernhofer, C., Burba, G., Ceulemans, R., Clement, R., Dolman, H., Granier, A., Gross, P., Grünwald, T., Hollinger, D., Jensen, N. Katul, G., Keronen, P., Kowalski, Lai, C.T., Law, B.E., 
Meyers, T., Moncrieff, J., Moors, E., Munger, J.W., Pilegaard, K., Rannik, Ü., Rebmann, C., Suyker, A., Tenhunen, J., Tu, K., Verma, S., Vesala, T., Wilson, K. and Wofsy, S. (2001) Gap Filling Strategies for Defensible Annual Sum of Net Ecosystem Exchange. Agricultural and Forest Meteorology, 107, 43-69. https://doi.org/10.1016/S0168-1923(00)00225-2

[22] Song, T., Wang, Y.S., Song, C.C., Shi, L.Q., Huang, Y. and Wang, P.X. (2006) $\mathrm{CO}_{2}$ Fluxes from Rice Fields of Sanjiang Plain and Its Environmental Response Factors. Journal of Environmental Sciences-China, 26, 657-661.

[23] Li, Q., Hu, Z.H., Xue, H.X., Wang, Y.L., Tan, T.T. and Wu, D.L. (2009) Variation of Net Ecosystem Carbon Flux over Typical Agro-Ecosystem in Huaihe River Basin. Journal of Agro-Environment Science, 28, 2545-2550.

[24] Barford, C.C., Wofsy, S.C., Goulden, M.L., Munger, J.W., Hammond, P.E., Urbanski, S.P., Hutyra, L., Saleska, S.R., Fitzjarrald, D. and Moore, K. (2003) Factors Controlling Long- and Short-Term Sequestration of Atmospheric $\mathrm{CO}_{2}$ in a Mid-Latitude Forest. Science, 294, 1688-1691.

https://doi.org/10.1126/science.1062962

[25] Hollinger, D.Y., Aber, J., Dail, B., Davidson, E.A., Goltz, S.M., Hughes, H., Leclerc, M.Y., Lee, J.T., Richardson, A.D., Rodrigues, C., Scott, N.A., Achuatavarier, D. and Walsh, J. (2004) Spatial and Temporal Variability in Forest-Atmosphere $\mathrm{CO}_{2}$ Exchange. Global Change Biology, 10, 1689-1706.

https://doi.org/10.1111/j.1365-2486.2004.00847.x

[26] Guan, D.X., Wu, J.B., Zhao, X.S., Han, S.J., Yu, G.R., Sun, X.M. and Jin, C.J. (2006) $\mathrm{CO}_{2}$ Fluxes over an Old, Temperature Mixed Forest in Northeastern China. Agricultural \& Forest Meteorology, 137, 138-149. https://doi.org/10.1016/j.agrformet.2006.02.003

[27] Wang, C.L., Yu, G.R., Zhou, G.Y., Yan, J.H., Zhang, L.M., Wang, X., Tang, X.L. and Sun, X.M. (2006) $\mathrm{CO}_{2}$ Flux Evaluation over the Evergreen Coniferous and BroadLeaved Mixed Forest in Dinghushan, China. Science China Earth Sciences, 49, 127-138. https://doi.org/10.1007/s11430-006-8127-3

[28] Liu, Y.F., Yu, G.R., Wen, X., Wang, Y.H., Song, X., Li, J., Sun, X.M., Yang, F.T., Chen, Y.R. and Liu, Q.J. (2006) Seasonal Dynamics of $\mathrm{CO}_{2}$ Fluxes from Subtropical Plantation Coniferous Ecosystem. Science China Earth Sciences, 49, 99-109. https://doi.org/10.1007/s11430-006-8099-3

[29] Flanagan, L.B., Wever, L.A. and Carlson, P.J. (2002) Seasonal and Interannual Variation in Carbon Dioxide Exchange and Carbon Balance in a Northern Temperate Grassland. Global Change Biology, 8, 599-615. https://doi.org/10.1046/j.1365-2486.2002.00491.x

[30] Xu, L. and Baldocchi, D.D. (2003) Seasonal Variation in Carbon Dioxide Exchange over a Mediterranean Annual Grassland in California. Agricultural and Forest Meteorology, 123, 79-96. https://doi.org/10.1016/j.agrformet.2003.10.004

[31] Li, F., Li, Q., Xue, H.X., Wu, D.L. and Wang, Y.L. (2012) The Impact of Temperature on Carbon Flux over Stipa krylovii Ecosystem during the Growing Season. Journal of Agro-Environment Science, 31, 1453-1459.

[32] Fu, Y.L., Yu, G.R., Sun, X.M., Li, Y.N., Wen, X.F., Zhang, L.M., Li, Z.Q., Zhao, L. and Hao, H.B. (2006) Depression of Net Ecosystem $\mathrm{CO}_{2}$ Exchange in Semi-Arid Leymus Chinensis Steppe and Alpine Shrub. Agricultural and Forest Meteorology, 137, 234-244. https://doi.org/10.1016/j.agrformet.2006.02.009

[33] Wang, W.J., Zu, Y.G., Wang, H.M., Matsuura, Y., Sasa, K. and Koike, T. (2005) Plant Biomass and Productivity of Larix Gmelinii Forest Ecosystems in Northeast China Intra- and Inter-Species Comparison. Eurasian Journal of Forest Research, 8, 21-41. 